\title{
Comparing Non-European Literatures - Dances of Mori Ōgai's The Dancing Princess and Sabahattin Ali's Madonna in a Fur Coat to the Music of Goethe
}

\author{
Dr. Devrim Çetin Güven \\ Dokuz Eylül University, Faculty of Letters \\ Department of Comparative Literature \\ devrim.guven@deu.edu.tr
}

\begin{abstract}
Comparative literature explores the influences of older "texts" on newer ones, through a cross-cultural, interdisciplinary, and multilingual perspective. Another common practice of comparative analysis is to study how Euro-American literary texts inspire nonEuropean ones, and vice versa. Yet, there is a methodological gap concerning the comparative studies that focus on non-European texts with no "direct" intertextual connection. On this basis, arguably, one of the most intriguing and creative ways of comparing two or more non-European works is to spot their common source texts. It is certainly not the only method of comparing non-Western texts, but it is indubitably an efficient method for positivistic intertextual analysis. This article aims to present a "case study" that may serve as a model for comparing non-European literatures. To this end, we focused on two works from Turkish and Japanese literatures that share remarkable resemblances, yet that do not have direct intertextual bonds: Mori Ōgai's The Dancing Princess and Sabahattin Ali's Madonna in a Fur Coat. As the major common source text that both refer to is Goethe's Faust, we traced how these two similar non-European works are affected by Faust, and how their intertextual dances with Faust contributed to their national and international literary reputations.
\end{abstract}

Keywords: Comparative literature, modern Turkish literature, modern Japanese literature, woman studies, translation.

\section{Avrupa-Dışı Edebiyatları Karşılaştırmak - Mori Ōgai'ın Dansçı Prenses ve Sabahattin Ali'nin Kürk Mantolu Madonna Eserlerinin Goethe'nin Müziği Eşliğindeki Dansları}

Öz

Karşılaştırmalı edebiyat kültür-ötesi, disiplinler-arası ve çok-dilli bir bakış açısından eski "metinler"in yeniler üzerindeki etkilerini araştırır. Bir başka yaygın karşılaştırmalı çözümleme uygulaması, Avrupa ve Amerikan edebî metinlerinin Avrupa-dışı olanları ve tersine, [Avrupa-dışı metinlerin Batılı olanları] nasıl esinlediklerini incelemektir. Ancak, "doğrudan" metinler-arası bağlantısı olmayan Avrupa-dışı metinlere yönelik karşılaştırmalı 
araştırmalar konusunda yöntembilimsel bir boşluk vardır. Bu bağlamda, muhtemelen, iki veya daha fazla Avrupa-dışı yapıtı karşılaştırmanın en cazip ve yaratıcı yollarından biri, bunların ortak kaynak metinlerini tespit etmektir. Elbette, Batılı olmayan metinleri karşılaştırmanın tek yöntemi bu değildir; ancak bunun pozitivist metinler-arası çözümlemenin en etkili yöntemlerinden biri olduğu şüphe götürmez. Bu makale, Avrupadışı edebiyatların karşılaştırılmasında model olabilecek bir "vaka çalışması" sunmayı amaçlamaktadır. Bu gayeyle, dikkate şayan benzerlikleri paylaşan, ancak aralarında "doğrudan" metinler-arası bağlar bulunmayan Türk ve Japon edebiyatlarından iki esere odaklandık: Mori Ōgai'ın Dansçı Prenses'i ve Sabahattin Ali'nin Kürk Mantolu Madonna'sına. Her ikisinin de atıfta bulunduğu başlıca ortak kaynak metin Goethe'nin Faust'u olduğundan, bu birbirine benzeyen iki Avrupa-dışı metnin Faust'tan nasıl etkilendiğinin ve Faust'la yaptıkları metinler-arası dansların, ulusal ve uluslararası edebî itibarlarına nasıl katkıda bulunduğunun izini sürdük.

Anahtar Kelimeler: Karşılaştırmalı edebiyat, modern Türk edebiyatı, modern Japon edebiyatı, kadın çalışmaları, çeviri. 


\section{INTRODUCTION}

In its most basic form, comparative literature explores the influences of older "texts" in the broadest sense of the word, be it literary or non-literary or even visual or performative works - upon newer "texts" through a cross-cultural, interdisciplinary and multilingual perspective. Furthermore, it also studies how the global zeitgeist (e.g., the global economic crisis of 2007-2008 or the current coronavirus pandemic of 2020-2021) affects literary or artistic production. Yet, literary comparisons must not necessarily be done exclusively on a "temporal" level; it can also be conducted on a "spatial" level. For instance, a most common practice of intertextual analysis is to study how European literary texts inspire nonEuropean $^{1}$ ones or on the contrary how non-European texts influence European ones.

Within this frame of reference, it would not be too much to say that the late $20^{\text {th }}$ and early $21^{\text {th }}$ centuries comparative literary theory has intensively handled the interaction of European and non-European literatures. From especially early 1980s onward studies of comparative literature have focused mainly on the de-centralisation of literary Eurocentrism which had been institutionalised under the guise of "universalism," in the aftermath of the fascist apocalypse caused by World War II, by such founding texts as Auerbach's (1946) Mimesis: The Representation of Reality in Western Literature and Warren and Wellek's (1949) Theory of Literature. Although there were a few exceptions like Moretti's (2000) "Conjectures on World Literature," which reproduces Eurocentrist ideology by positing "Europe" as the literary/cultural "core" that unilaterally influences non-European "periphery" literatures, most comparative studies (or studies with a comparative perspective) published during this period explored the interaction of European and non-European literatures through a centrifugal perspective (Ahmad, 1994; Apter, 2003; Bassnet, 1998; Damrosch, 2003; Eagleton, Jameson \& Said, 1990; Karatani, 2004; Said, 1994). The reference point of these studies was indubitably Said's (1978) Orientalism, to which they referred either positively or negatively -Ahmad (2000, pp. 159-220) lambasts Said's Orientalism from a Marxist and radical postcolonial point of view - or retroactively -Karatani (2004, pp. 279-281), who read Said's Orientalism (1978) after his theoretical book Origins of Modern Japanese Literature had been published (in 1980), maintains that both books have astonishingly common perspectives. One of the common approaches shared by most of these works is a tendency to oppose Eurocentric pseudo-universalism through a revaluation of "national literatures" and postcolonial cultural "nationalism" -in the broadest sense of the word- which had been a taboo until the 1990s.

On the other hand, although there exist myriads of studies on the interaction of European and non-European national literatures, there is a methodological gap concerning the comparative analyses of two or more non-European texts that are very similar and that appear to have no direct intertextual connection to each other. This article aims to present a case study that may serve as a model for comparing non-European "texts." On this basis, arguably, one of the most intriguing and creative ways of comparing non-European literatures is to spot their common source texts. It is certainly not the only method of comparing peripheral texts, but it may be considered an efficient method for positivistic intertextual analysis. Yet, first of all, one must explain why one should engage in such a

${ }^{1}$ In this article the term non-European literatures is used in its broadest sense, signifying the national literatures of the countries that are not located in Europe or North America. An alternative term could be non-Euro-American literatures.

SEFAD, 2021; (45): 81-100 
study. If you are an avid reader of world literature, reading books from various territories of the planet systematically or at random, you sporadically undergo the following experience: you are shocked as you recognise striking similarities between two texts belonging to totally different cultures. To make the matter more complex, they are deprived of the possibility of exerting a "direct" influence on one other since they are not translated into neither each other's language nor into major European languages like English, French, German etc. Then you have two options: either you will conclude that this commonality is but a mere coincidence or you will consider the probability that they might have been influenced by the same foreign "texts" (again in the broadest sense of the word), which usually are internationally renowned ones.

The common source texts can be Antiquity classics such as Sophocles' King Oedipus or universal masterpieces like Goethe's closet drama Faust, cultural theories like Freud's Madonna-whore complex, even consumable, best-selling pulp fictions like Agatha Christie's whodunits, e.g. Murder on the Orient Express, and once popular medieval chapbooks like Johann Spies' Historia von D. Johann Fausten. Needless to say, other genres of art -which could be defined as "non-textual texts" - such as cinema, opera, symphony, oratorio, ballet, theatre, painting, photography etc., could also constitute inspirational sources for two (or more) non-European works bearing similarities. Detecting the common sources for unconnected periphery works would render the epistemological processes of comprehension and interpretation richer and profounder.

In this framework, a convenient example may be a comparison between two texts belonging to Turkish and Japanese literatures that share remarkable resemblances. For instance, a careful reader who happens to have read Mori Ōgai's The Dancing Princess (『舞 姫』=Maihime, 1890) ${ }^{2}$ and Sabahattin Ali's Madonna in a Fur Coat (Kürk Mantolu Madonna, 1943) consecutively, would be struck by the similarities they bear. Both texts treat similar themes and stories: a tragic cross-cultural love affair between a foreign man who stays in Germany for study or work and a local woman, ending with a tragic finale of separation and the woman's "death," be it physical or spiritual (i.e., insanity). The reader's surprise becomes even stronger when she/he learns that it is highly unlikely that Sabahattin Ali could have read this story which was published more than half a century earlier than the publication of his work, since it had not been translated then neither into Turkish nor into any other foreign language he has a high command of, such as German. If Sabahattin Ali had never read a translation of this book, namely if any direct intertextual channel between him and Mori Ōgai was out of question, how could such a resemblance have been possible?

At first glance, both being tragic love stories treating the most clichéd romantic themes of "love and death," it is no big surprise that these works are similar. Furthermore, if one considers the fact that both are semi-autobiographical stories based on the equivalent experiences of studying/working in Germany and falling in love head over heels with a local woman, this correspondence becomes even more self-evident. However, when one considers the specific thematic common points of The Dancing Princess (cited as The Dancing henceforth) and Madonna in a Fur Coat (cited as Madonna henceforth) listed below, one is still tempted to think that they might be referring to identical literary sources: 1) The nonEuropean protagonists (The Dancing: Ōta Toyotarō (太田豊太郎) and Madonna: Raif) go to

${ }^{2}$ This short story's title was reductively translated as The Dancing Girl by Richard Bowring. In the present paper, The Dancing Princess, which is a direct equivalent of the original title will be used. 
Berlin for their studies and works; 2) They work as skilled translators/interpreters of German; 3) The protagonists fall in love with women who have German citizenship (The Dancing: Elise Weigert and Madonna: Maria Puder aka Madonna in a Fur Coat); 4) The women work in the world of musical and performative entertainment (The Dancing: Elise Weigert is a dancer at the Viktoria Theatre and Madonna: Maria Puder is a singer and violinist); 5) The women are depicted as outcasts or marginal figures in their societies; 6) The women become pregnant to the babies of the protagonists; 7) They become ill with heavy consequences; 8) The protagonists lose their parents while they are in Berlin (The Dancing: Öta's mother; Madonna: Raif's father); 9) The protagonists are forced to leave Germany; 10) The women die either physically or spiritually (The Dancing: Elise goes mad; Madonna: Maria dies of illness); 11) Their physical or mental death out of illness is explained as deaths linked to the eventually unrequited love for the non-European protagonist.

As we will assert in what follows, the major source text that both works refer to is Goethe's Faust. In this article, we will trace how these two non-European literary works sharing close resemblances were affected by Faust. We will also attempt to expose how these intertextual influences have contributed to the national and international literary reputations and popularities of these works. In this way, we aim to make a contribution to the methodology of comparative literature concerning the intertextual analyses of non-European literatures.

\section{A COMPARATIVE ANALYSIS OF THE NARRATIVE CONTENTS OF THE DANCING PRINCESS AND MADONNA IN A FUR COAT}

Before anything else, it would be appropriate to present the narrative contents of The Dancing and Madonna, i.e. "what" these stories recount, prior to analyse "how" their intertextual dances with Goethe's Faust are performed. Mori Ōgai (森鴎外1862-1922), who combines various professional identities such as Japanese Army Surgeon general officer, translator, novelist, and poet, is one of the prominent figures of modern Japanese literature. After graduating from the medical school, Mori became a deputy surgeon of the imperial Japanese army. The army sent him to Germany with the aim of surveying and studying how hygiene is administered in German Land Forces from 1884 to1888. Accordingly, The Dancing is loosely based on the love affair he had with a German woman during his stay in Germany. Therefore, the short story has some autobiographical aspects. What follows is the plot summary of The Dancing.

Ōta Toyotarō, a young, polyglot, and promising public servant, is sent to Berlin by a certain ministry to study law and political sciences. Yet, the enticing atmosphere distracts and enables him to discover his new, true self. In the university he becomes interested in literature and history, eventually he changes his subject to arts. This Faustian process of reinvigoration is completed by his love for Elise Weigert, a beautiful sixteen or seventeenyear-old German dancer whom Ōta sees one day sobbing against the closed door of a church. He asks her what the matter is, and she answers that her father has just died, yet they cannot bury him as they are destitute. We learn later, along with Ōta that what caused her tears was also the indecent proposal of her vicious manager at the Viktoria Theatre, in return for the funeral fee. As Ōta covers the burial fee their friendship begins.

However, due to this friendship Ōta is accused of neglecting his studies. Consequently, his post is abolished, and his employment terminated. To make the matter 
worse he receives the news of the death of his mother who -being his only parent - was so dear to him. In the meantime, Ōta's feelings towards Elise change to one of love. He begins to work as the foreign correspondent of a Japanese newspaper and moves to Elise's house to live with her and her mother and their relationship takes the form of common-law marriage whose bitter fruit would be Elise's pregnancy. One day, his friend Aizawa, who came to Berlin as part of Count Amakata's suite, introduces him to the Count. After testing him with the translation of some documents, the Count hires him as his personal translator. In return Ōta reluctantly promises Aizawa to leave Elise soon. After an official visit to Russia, the Count, who is satisfied with his performance, offers him to go back to Japan, which is an opportunity for him to restore his career as a bureaucrat. However, on the way home he has a severe panic attack triggered by his guilty conscience which leaves him unconscious for some weeks. As he regains consciousness, he learns that Aizawa has told her about his plans of returning to Japan. The sudden trauma of learning about her lover's betrayal triggers an irrecoverable psychosis in this young pregnant woman. Much to the readers' surprise, Ōta, who is currently scribbling these notes on board of a ship bound for Japan, blames chiefly Aizawa for Elise's tragic end rather than himself.

Tantamount to The Dancing, Madonna's main story is related retrospectively in the form of diary notes. Yet, being a novella unlike The Dancing, Madonna is much longer and has a more complex structure. Additionally, it is a story within a story that consists roughly of three sections that are asymmetrical in length: 1) The anonymous narrator's own story and the account of his making acquaintance with Raif; 2) The diary notes in the black-coated school notebook of Raif concerning his love affair with Maria Puder, constituting the longest part of the novella; 3) The narrator's short interpretation of the diary notes and announcement of Raif's death.

The jobless narrator is employed by an old classmate who is by now the assistant director of a trading company where he shares the same office with Raif, a middle-aged translator, appearing to be a dull man. He is harshly exploited in the firm as he is a hardworking translator with a high command of German -just like Ōta is. He is sadistically mocked by his younger colleagues. Nevertheless, the narrator's low esteem changes drastically when he finds a masterfully drawn caricature of his boss on Raif's desk. Thus, he realises that Raif has in fact a very deep interiority. Although the narrator desires desperately to infiltrate Raif's world, he cannot do so as he is a hermit-like reclusive and opaque man. Opportunity knocks when Raif falls ill because of his suicidal actions-i.e. "walking down deserted streets for hours in the night, through wind and snow, opening up his chest" to the frosty cold of Ankara (Ali, 2016, p. 60). Among Raif's belongings that the narrator brings from the office is his diary. Raif asks to burn it down in the stove lest any stranger access his past, which is ironically the very reason the narrator wants to preserve it. After a tough negotiation, the narrator finally manages to convince the dying man by saying that he wants to take lessons from his life experiences.

Hence, the narrator returns to his hotel room and begins to read the notes of Raif. They are kept recently, in June 1933, but they concern approximately the period between late 1910s to early 1920s, i.e., the process of the cruel dismemberment of the Ottoman Empire by British, French, Italian and Greek forces as well as the subsequent national war of liberation against this imperial occupation. Fearing that his son might join militia forces fighting for the independence, his father sends him to Germany under the pretext of learning production 
techniques of scented soaps. Thus, akin to his Japanese counterpart Ōta, Raif goes to Berlin where he lives like almost a dilettante, especially delighting in frequenting painting exhibitions while working as a part-time trainee in a Swedish soap factory. One day, in a gallery he literally falls in love at first sight with a self-portrait which is renamed by a critic as "Madonna in a Fur Coat." He begins to watch this painting every afternoon for hours, till one day its painter approaches and talks to him. Yet, because he is extremely shy with women in the same way as Ōta is, not being able to look at her face he fails to notice that she is the very Madonna he has been dreaming about. One night he follows a woman whom he believes is Madonna. She turns out to be a singer and violinist. Raif enters the cabaret where she performs. After her performance she stops at Raif's table and talks to him. He realises that the woman who approached her i.e. Maria Puder and Madonna are one and the same person. Then their relationship starts as a non-sexual friendship mainly because of Maria's androphobia and commitment anxiety. On the New Year's Eve, they go to a large establishment called Europa where they dance to the waltz music. Maria steps out without taking her fur coat, thus exposing her body to the frost, eventually she catches a cold - which is an intra-textual contextualisation of, and proleptic remark for Raif's future suicidal actions. Worrying for her health, Raif spends the night with Maria; thus begins their love affair, yet she keeps her cynical attitude. Then Maria's cold worsens and turns into pleurisy. Only after seeing Raif's selfless efforts for her recovery, would her androphobia be healed, and she would let herself love him back.

Nonetheless, due to his father's death, Raif is forced to return to Turkey. Meanwhile he makes the necessary arrangements for Maria's coming. However, shortly after she wrote to him that she had some very good news for him, for which he would have to wait until she joined him, her letters stop, and Raif's subsequent letters are returned. Over the course of time, judging that she betrayed him, he marries another woman and have children. Following his bankruptcy, he takes his family (as well as his wife's sister and brothers, as he is forced to look also after them) to Ankara and begins to work in a trading company (where he currently works). Despite all this, being unable to forget Maria, Raif still suffers pangs of love. This continued till a day ago when he encountered his former neighbour, a Dutchwoman, Frau Döppke accompanied by a small girl, waiting for her train bound for Baghdad where she will join her new husband Herr Döppke, a German colonial tradesman. Raif who knows that Döppke is a relative of Maria, asks her reluctantly about Maria, pretending to be a fan of her paintings. Döppke tells him that Maria was pregnant to the child of a Turk who was then in Turkey, and that ignoring all the warnings of the doctors she gave birth to a girl at the expense of her life. Then she says that she adopted Maria's daughter, adding that the small child in her company is that very girl. As a matter of fact, Döppke knows everything yet she sadistically enjoys tormenting Raif since she still holds a grudge against him, because he had not responded to her promiscuous advances. Hearing all this shocking news and having to wave hands to his daughter and her vicious stepmother, leaving on a train bound for Baghdad and an obscure future, devastates Raif totally. Ever since that day he has become a "living dead." Having discovered the secret of Raif, the narrator calls at his home. Yet he is already dead. Then the narrator decides to preserve the book which he thinks is too precious to burn.

Sabahattin Ali (1907-1948) is one of the most popular writers and poets of modern Turkish literature. In 1928, he was sent to Germany by the Ministry of Education to be 
trained as a high school teacher of German. First, he stayed in Potsdam then he went to Berlin and is admitted to a boarding school where mainly the children of the aristocrats and army officers are enrolled. Yet, he was deported in the spring of 1930, as a result of a quarrel with a group of racist students. His novella Madonna is loosely based on his experience of a platonic love with a German woman named Fräulein Puder during his stay in Germany. Additionally, some of Ali's close friends claimed that the author must be inspired by Lili, a blonde Hungarian-Jewish woman who was a violinist in a women's orchestra performed in Istanbul. They insist that this friend of Ali, who used to wear a grey fur coat, must be the model for his heroine, and indubitably the strange title of his book (Bezirci, 2007, pp. 206207). Thus, in the same manner as Mori's The Dancing, Madonna has autobiographical aspects as well.

Madonna was serialised in a newspaper entitled Hakikat (Truth), from 18 December 1940 to 8 February 1941 and finally published as a book in 1943. However, unlike The Dancing, critics regarded it as a mediocre book for more than half a century, attracting little interest compared to his other literary works. According to Ali himself, the most important reason of this failure was the newspaper's "sloppy presentation" (Bezirci, 2007, pp. 204-205). Despite all this, in the 2010s, approximately seventy years after Madonna was published, it was re-discovered by the new generation of readers and is still one of the bestselling books. The novella came anachronically to be regarded as an essential part of $21^{\text {st }}$ century Turkish literature, as it corresponded perfectly to the expectations of the contemporary audience. In this regard, it is similar to Kobayashi Takiji's Crab Cannery Ship (1929) which was rediscovered eighty years after its publication and is re-defined as "the unexpected guest of $21^{\text {st }}$ century Japanese literature" (Güven, 2018, pp. 29-30). Hence, both Madonna and Crab Cannery Ship have acquired the status of widely read national classics today, and are remarkable works of the non-European world literature canon.

In this context, one of the best methods to be applied in comparing non-European literatures is to study "how" they become popular, "how" they acquired the status of national classics, and -if it is the case- "how" they are included in international canons. On this basis, two questions can be asked: What are the factors that enabled The Dancing to have become a popular work among the classics of modern Japanese literature? How and why have Madonna been forgotten for more than half a century, then rediscovered and became part of both Turkish and world literature canons? A major determinant for these is their interaction with European modern literature and culture, especially with Goethe's Faust.

\section{GOETHE'S FAUST AS THE COMMON EUROPEAN SOURCE TEXT}

As we mentioned above, one of the major source texts that affected these two nonEuropean stories is Goethe's closet drama, Faust. However, in comparative literature this is certainly not an end, but a beginning. For the key question in comparative analysis is not "what," but "how." Namely, what one should focus on is not spotting "what" is the source text that affects non-European texts (e.g. The Dancing and/or Madonna), but is to analyse "how" that source text exerts influence on non-European texts. Indubitably, in comparative literature, it is crucially important to detect "what" the source text is, which is indeed one of the attractions of comparative readings. However, it is much more important to determine "how" the influence is exerted rather than "what" the source text is. For instance, determining that Faust affected The Dancing does not bring us much, since Mori "is the first 
and greatest translator of German literature," so much so that "his translations can almost be called a part of Japanese literature" (Takahashi, 1960, p. 194). Even more critically, he is the first translator of the full text of Faust. For instance, Takahashi Kenji relates how ground-breaking Mori's translation of Faust was:

\begin{abstract}
Surpassing [his other translations], however, was his translation of Faust which, appearing in 1913, was an epoch-making achievement in the history of the introduction of foreign literature into Japan. This was not only because of the historical magnitude of the original work, but also because of the way [Mori] Ögai's translation, through its lofty Japanese, made it possible for Japanese readers to appreciate this difficult masterpiece.
\end{abstract} (1960, p. 196)

Additionally, Rimer and Gessel (2011, p. 8) underlines how Mori modelled after Faust, and combined it with his emotions concerning his love affair in Germany: "His attempts to describe his emotional experiences during these years abroad, most notably in The Dancing Girl [...] owe much to Goethe and the later continental writers he had come to admire. Indeed, this early work brought a new dimension to the literary expression of personal emotions in Japanese literature." To recapitulate, Mori, who was an effective translator of German literature, was inspired by Faust while writing The Dancing. Moreover, it is noteworthy that he translated Faust twentythree years after The Dancing's publication. Needless to say, all this adds a different dimension to the issue of "how" Mori was influenced from Faust. Therefore, here a different type of intertextual influence is the case. One is even tempted to say that in The Dancing Mori did not merely modelled after Faust, but he conceived it as a preparation for its upcoming translation. Furthermore, this assumption acts in concert with the spirit of Faust which has always been subjected to a process of cultural transfer through translation in every sense of the word. Hence, although translation is generally seen as instrumental, Mori converted translation into an end, while turning creative writing into a means of translation.

On the other hand, although Faust did not affect Madonna as intensely as it did The Dancing, it is not surprising that Ali is inspired by it. For, he had also close bonds with German language and literature. He is not only an avid reader of German literature, but also the translator of such German authors as Lessing, Heinrich von Kleist, and E. T. A. Hoffmann. Thus, both Mori and Ali are translators of German literature; this commonality on the level of authors could also be observed on the level of the protagonists as both Öta and Raif are translators of German. Furthermore, although unlike Mori, Ali did not translate his works, Goethe was his favourite German writer along with Thomas Mann (Sertel, 1977, p. 276).

So far, we attempted to demonstrate how the involvements of Mori and Ali with German language and literature might have affected their works modelling after Faust. Yet before deepening our analysis, it is necessary to present a detailed plot of Faust.

\title{
The Plots of Goethe's Faust Part One and Part Two
}

Faust, Part One (Faust-Eine Tragödie, published in 1808, revised in 1828-1829), which is the multiply revised edition of Urfaust (written in 1772-1775; published posthumously in 1887) and subsequently Faust, a Fragment (Faust, ein Fragment, 1790), opens in heaven. Mephistopheles enters heaven where three Archangels, Raphael, Michael, and Gabriel praise God's greatness as being beyond understanding. Defying them and God, Mephistopheles denounces God for humans' misery saying that humans are corrupted and use their reason 
only for bestial and cruel purposes. God replies that he trusts Dr. Heinrich Faust, the famous scholar whom he thinks incorruptible. Then God and Mephistopheles make a bet with each other about whether Faust would be tempted by the devil, i.e. Mephistopheles, and lose his way or not. Meanwhile on earth, Faust is undergoing a neurotic identity crisis, as he could not attain a genuine knowledge through science. He turned to magic and pseudoscience, but they have also been useless. Out of despair, he even considers suicide, but renounces it as he hears the church bells ringing for Easter. Then Mephisto visits him several times in various disguises (a black poodle, a religious figure, and a nobleman) and makes him an offer: he will become Faust's slave, do everything he asks, in return Faust will become his slave in Hell and serve him unconditionally. Faust adds an extra condition to this offer, turning it into a "wager": Faust will become his slave only if he is fully satisfied with what Mephistopheles provides him, so much so that he would desire to remain in that very moment, only then he can die happily, and his soul may belong to the devil.

Thus, after Mephistopheles accepts this wager, Faust signs away his soul to him. Subsequently, Mephistopheles has a witch rejuvenate Faust. Then Faust encounters a beautiful girl (Margarete) in the street and makes her an indecent proposal, but she rejects it, both due to her inferiority complex and high morals. Faust demands Mephistopheles to have her fall in love with him. But the devil has no direct power over her as she is innocent. After some attempts, however, Mephistopheles manages through dirty tricks to have her fall in love with Faust. Although his initial attraction to the girl had been sexually motivated, it gradually changes to that of love. Faust, who had been tempted by Mephistopheles, now tempts her indirectly to several sinful acts. Firstly, he gives her a "sleeping potion," which was supposed to enable them to have sexual intercourse without being bothered by her mother, turns out to be a poison that would eventually kill her. Meanwhile, feeling humiliated by his sister's love affair, Valentine, Margarete's brother, challenges Faust and eventually gets fatally stabbed by him. He curses her before dying. Margarete's tragedy becomes even more intense, as she drowns her illegitimate baby. Subsequently, she is arrested and sentenced to death for infanticide. When Faust learns about what happened to her, he denounces Mephistopheles and asks him to free her. Yet he answers that his power is limited, and that he can only help him to some extent. They arrive at the prison; Faust goes to Margarete's cell to save her who is half in a state of frenzy. She is blissed out as soon as she recognises him. Yet she does not want to escape with him since she wants to pay the price of her sins. As she sees Mephistopheles her reaction gets even harsher, she denies any help of the devil. Faust is forced to leave without her, hearing her desperate cries.

Faust, Part Two or more precisely Faust: The Second Part of the Tragedy in Five Acts (Faust. Der Tragödie zweiter Teil in fünf Akten, published posthumously in 1832) is set several years later than Margarate's execution. Faust begins to serve the Emperor, who is a mediocre ruler having hard time because of the economic crisis and poverty. Faust and Mephistopheles successfully rebuild the country's economy. Subsequently, he journeys to the (under)world of Greek mythology, in the guise of a medieval lord, accompanied by Homunculus (an android or pure soul without body, invented by Wagner) and Mephistopheles. This journey is in fact a quest for Helen, the embodiment of ideal beauty. Faust is lucky enough to be able to marry Helen -more specifically her spectre - and even to have a son with her, Euphorion. Yet, this Byronic figure incarnating the artistic genius, dies young due to his passionately romantic character: he pursues ambitiously an impressive 
chorus girl into the sky, climbing the cliffs and flying up only to fall back down to his Icarian death. In the wake of this tragedy Helen leaves Faust and returns to Hades to live there with his son's soul.

After returning to the real world, Faust and Mephistopheles lead the emperor to victory with their skilful tactics, and as a return for this victory they are given a vast fiefdom. Yet one day, Faust's eyes are blinded by a female spirit named Care, in the disguise of a grey woman as a punishment for violently expropriating the land of an old couple causing their death - although their death was mainly Mephistopheles' fault. The blinded Faust, presently one hundred years old, attempts to undertake a final utopian project of land reclamation. He wishes to create an Edenic, idyllic space with fertile fields where millions of people would live freely. Yet one day he mistakes the clanking of the Lemures' (ghostlike creatures in Roman mythology) shovels for the realisation of his humanitarian undertaking -the Lemures are in fact instructed by Mephistopheles to dig dying Faust's grave. Thus, Faust says, "If only [he] might see that people's teeming life, share their autonomy on unencumbered soil; then, to the moment, [he] could say: tarry a while, you are so fair the traces of my days on earth will survive into eternity!"(Goethe, 2014, p. 292). Since, according to the contract uttering these words gives Mephistopheles the right to appropriate Faust's soul, Mephistopheles becomes confident that he won the bet. Nonetheless, although he intends to hold Faust's soul by the help of a horde consisting of Fat and Thin Devils, Faust is saved by some angels who intervene. Subsequently, they conduct his soul to heaven where Margarete's soul demands Mary/Madonna to save Faust's soul. Mary/Madonna tells her to fly upward so that Faust follows her and achieves salvation.

\section{FAUST AS A WORK WITH HIGH INTERTEXTUAL CONTAGIOUS POWER}

When Goethe made his first acquaintance with this legend in a puppet show as a small boy (Wellbery, 2014, p. xix), it had already proven its high contagious power like a pandemic. Namely, Faust had already been the epitome of rewriting and intercultural circulation throughout European literature. As Johann Spies, a German printer published the chapbook entitled Historia von D. Johann Fausten (1587) written by an anonymous author, relating the legendary story of Dr. Johann Georg Faust, a $16^{\text {th }}$ century German astronomer and necromancer who allegedly sold his soul to the devil, it became the subject of many rewriting and (re-)translation practices. Christopher Marlowe, who read the English translation of this chapbook, The Historie of the Damnable Life, and Deserved Death of Doctor Iohn Faustus, (ca. 1590s), was so much impressed by it so that he immediately re-wrote it in the form of a play: The Tragical History of the Life and Death of Doctor Faustus (ca. 1590s).

Decades later, Goethe, the great poet of Weltliteratur, decided to transfer Faust back from England to Germany. He continued re-writing Faust as a closet drama, sporadically from 1772 to 1831 , i.e., the age of twenty-three to the age of eighty-two, throughout almost sixty years. Faust, Part Two was posthumously printed in 1832. Hence, we may easily define it as a process of constant re-writing. Particularly, Goethe's version, which he continued to rewrite throughout his lifetime, would be the main inspiration for myriads of literary, cinematic, and musical Faust adaptations. For instance, one of the most famous examples of literary adaptations is Thomas Mann's Doctor Faustus: The Life of the German Composer Adrian Leverkühn, Told by a Friend (Das Leben des deutschen Tonsetzers Adrian Leverkühn, erzählt von einem Freunde, 1947). This novel, set mainly in 1930s, presents a bleak portrayal of the rise of 
Nazism through its protagonist Adrian Leverkühn, a famous composer who deliberately contracts syphilis -which has a Mephistophelean function - with the aim of improving his skills and creativity as a musician. Furthermore, as is widely known, Goethe's Faust has been an inspiration for many musical adaptations in the genres of opera, symphony, rock, and heavy metal. Hence, the contagious power or the "regenerative potency" of Faust is indeed extraordinary, so much so that according to Welberry (2014, p. xix) "only the legend of Don Juan evinces such regenerative potency."

\section{"DIFFERENCE" AND "DEFORMATION" AS FUNDAMENTAL ELEMENTS OF COMPARATIVE LITERATURE}

What is essential in comparative literature is not to focus on the similarities between texts, but on their "differences." In other words, comparative literature explores how the narrative discourse or content of the source text is deformed in the other texts that are influenced by it. Hence, Bachelard's (1943, as cited in Kurczynski, 2014, pp. 129-130) thesis on the relationship between imagination and deformation is valid for intertextual analysis: "one always wants imagination to be the capacity to form images; however, it is rather the capacity to deform images, furnished by perception, [...] to liberate us from initial images, to change images." For instance, the most important Faustian element that The Dancing and Madonna import and creatively reconstruct is its heroine Margarete. Thus, although both Elise and Maria are modelled after Margarete, they are the deformative reconstructions of her.

Elise as a Failed Attempt of Constructing Woman-Worship in Modern Japanese Literature through the Image of Margarete

In The Dancing, Mori intended to construct the romantic motifs of "love" and "woman worship." These quasi-romantic overtones, which were absent in Japanese literature of the time, are among the factors that paved the way for the work's popularity as soon as it was published in 1890. Indeed, the theme of "woman worship," or exaltation of female beauty were erased from Japanese literature in the Edo Period (1603-1868) where Buddhism was suppressed. This issue was addressed by Kaname, the protagonist of Tanizaki Junichiro's Some Prefer Nettles (1928):

[Kaname] found in foreign novels, music, movies something that satisfied it a little, probably because of the Occidental view of women. The tradition of woman-worship in the West is a long one, and the Occidental sees in the woman he loves the figure of a Greek goddess, the image of the Virgin Mother. The attitude so pervades the customs and traditions of the West that it automatically finds expression in art and literature. Kaname had an intense feeling of loneliness and deprivation when he thought of the emotional life of the Japanese, so lacking in this particular feeling of worshipfulness. Ancient Japanese court literature and the drama of the feudal ages, with Buddhism a strong and living force behind it, had in its classical dignity something of what he sought, but with the Edo shogunate and the decline of Buddhism even that disappeared. While the dramatists and novelists of the Edo period were able to create soft, lovely women, women who were likely to dissolve in tears on a man's knee, they were quite unable to create the sort of woman a man would feel compelled to kneel before. Kaname therefore preferred a Hollywood movie to a seventeenth-century Kabuki play. (2010, p. 34)

The literary or dramatic female figure that Kaname, a Euro-centrist intellectual, thinks is absent in Japanese literature, corresponds to Margarete, since she is a character who has 
metaphoric links with the Homeric Helen of Troy and Virgin Mary/Madonna. The leading authors of Modern Japanese literature like Mori, Natsume Soseki, Tayama Katai, Shiga Naoya, and Arishima Takeo strove to re-construct the romantic motifs of "woman worship" and "passionate love" which are the indispensable elements of European literature. According to Takahashi (1993, p. 1247), in his era, Mori was the most successful writer in terms of producing a vivid and colourful woman portrayal especially in The Dancing compared to the dull, static, and commonplace woman portrayals of Natsume Soseki. The Dancing was also instrumental in the formation of Japanese I-novel (shi-shōsetsu/私小説) genre that consists usually the confessions of love sins of the protagonist. Donald Keene addresses this issue briefly in what follows:

The Dancing Girl was, in Mori's words, an "Ich roman" [I-novel]-a story so closely based on personal experiences as to be a kind of dramatized diary. This type of autobiographical fiction was to occupy a disproportionately large place in modern Japanese literature. (2007, p. 23)

One is tempted to say in passing that Mori's "dancing girl" Elise would be creatively resurrected as a young Japanese danseuse by Kawabata Yasunari in his novella The Dancing Girl of Izu (『伊豆の踊子』, 1926) which is a refined example of I-novel genre. Moreover, modern critics praised this story for its elegant style (gabun-tai=雅文体) that skilfully fuses Japanese and traditional Chinese writing styles. These aesthetic features paved the way for The Dancing to become the forerunner of Japanese romanticism (Takahashi, 1993, p. 1249). However, if we read the text carefully, we can easily notice that Elise has a very meagre and gradually decreasing presence, especially when she is compared to her intertextual model Margarete. For instance, this can be observed in the finale of The Dancing:

\begin{abstract}
I recovered from my illness completely. How often did I hold her living corpse in my arms and shed bitter tears? When I left with the count for the journey back to Japan, I discussed the matter with Aizawa and gave her mother enough to eke out a bare existence; I also left some money to pay for the birth of the child that I had left in the womb of the poor mad girl. Friends like Aizawa Kenkichi are rare indeed, and yet to this very day there remains a part of me that curses him. (Mori, 2011, p. 23)
\end{abstract}

Thus, compared to the strong presence of Margarete, who is both juxtaposed with and metaphorically related to Helen, the symbol of ideal beauty in Greek mythology and literature, and to Mary/Madonna who is the emblem of spiritual beauty and motherhood of Christianity, Elise appears like a secondary character. As is clear in the finale, the narrator depicts her as a mindless body through a cold, almost scientific discourse which evokes a medical doctor's case report, and which obliterates the romantic elements that were borrowed from Faust, Part One. Perhaps this is not too exceptional when one considers that its author is a professional physician practicing modern medicine. Hence, the medical gaze that dehumanises human beings by relegating them into mere bodies without minds and that we observe in many works of modern world literature like Ooka Shōhei's Fires on the Plain, Sartre's The Wall, Conrad's Heart of Darkness, and Rifat Ilgaz's Nights of Blackout (Güven, 2020) is also at work here.

Indeed, as seen in Ōta's phrase "her living corpse," towards the end of the narrative, Elise becomes a body deprived of consciousness, and almost invisible. In the last sentence, Ōta avoids taking any responsibility for the spiritual death/insanity of Elise, instead he blames his friend Aizawa -one of the Mephistophelean figures of the narrative. Such a 
portrayal of Elise is not only far from constructing a female character as a figure of romantic love that the author intends to do, but also prepares the ground for a patriarchal, malecentred, and misogynist ideology. Thus, Mori failed to construct a romantic atmosphere of love and "woman worship." But what does underlie this failure? Firstly, as is evident in Ōta's selfishly choosing his career over his love, The Dancing affirms and reproduces the fashionable and prevalent ideologies of modernising Japan, namely, careerism and individualism. Bureaucratic careerism was romantically criticised by Futabatei Shimei in his unfinished novel Drifting Clouds (Ukigumo=『浮雲』, 1888) which was published two years earlier than The Dancing. Moreover, the destructive nature of individualism was denounced by Natsume Soseki in Kokoro (『こつろ』, 1914). In this sense, it can easily be said that The Dancing is a politically pro-modernist "national allegory" (Jameson, 1986, p. 68) of post-1868 Meiji Restoration Japanese modernisation that paved the way for the Japanese militarism and imperialism (1868-1945).

Provided that many critics style Faust as "the poem of modernity" (Wellbery, 2014, p. xvii), it is not hard to assume that Mori was inspired by this feature while building his own allegory. Nonetheless, unlike Mori, Goethe as the author of Faust criticises some features of modernity such as money, materialism, urbanisation, careerism, individualism, imperialism etc. In that sense, Goethe's poem of modernity is rather an elegy than a hymn for the ongoing capitalist modernisation which causes many human crises on both individual and social levels. Hence, Mori's inability to create a romantic atmosphere is partly caused by his professional and national identities. Namely, just like his ambitious protagonist Ōta who cannot choose Elise over his professional career, Mori is unable to dissociate himself from his national and professional identities as a general officer and medical doctor of the modernising Japan.

\section{Sabahattin Ali's Madonna in a Fur Coat as the Deconstruction of Freud's Madonna- Whore Complex and Goethe's Margarete}

On the other hand, the failure of Elise's characterisation has also to do with the narrative discourse of the text, i.e. "how" the story is written and structured modelling after Faust. As we asserted above, The Dancing is Mori's preparatory text for the imminent Faust translation. Nevertheless, in this practice, the source text is not the entire text of Faust, but exclusively Faust, Part One. As mentioned earlier, Part One ends with Margarete's becoming insane and her upcoming execution for infanticide. She is doomed to die as a sinner, i.e., as someone causing the deaths of her family members. Thus, at the finale of this part, the heroine as the object of "romantic love" and "woman worship," is deprived of her subjectivity, she is marginalised and finally excluded from the narrative space. By contrast, Part Two's finale presents a Margarete -endowed with a strong subjectivity, almost exalted to the status of a goddess - who saves the soul of Faust with the assistance of Mary/Madonna. Hence, Part Two produces a matriarchal ideology that does not fit with neither feudalism nor modern capitalism. Furthermore, with its very heterogeneous, grotesque, and multiform narrative content, it bears a strongly carnivalesque atmosphere peculiar to pre-modern literatures. Thus, Mori ignored Part Two as it does not comply with the standards of modern realist literature, while he relied exclusively upon Part One. Although this exclusion acts in concert with his political and literary modernist stance, it induced his failure in constructing a vivid motif of "woman worship" which is a prerequisite for a romantic love story. 
Ali's Madonna, on the other hand, unlike The Dancing, has a quasi-feminist sensitivity. It exalts woman as an object of worship, while belittling the presence of men-Maria Puder is depicted as a much stronger person than Raif, almost like his father. Thus, evidently, the novella refuses traditional gender roles (Freely, 2016), as it often emphasises Raif's feminine and Maria Puder's masculine aspects. In addition, Madonna, is a successful romantic "love story" which treats skilfully the motifs of "woman," "woman worship," and "love." One of the structural factors behind this was that Ali was not inspired exclusively by Faust, Part One, on the contrary, he was much more conscious of Faust, Part Two while writing Madonna. For, as mentioned above, Margarete's strong presence is both juxtaposed with and metaphorically related to Helen, the symbol of worldly beauty and to Mary/Madonna who is the emblem of otherworldly, spiritual beauty and motherhood. Although Margarete who was tempted to sin by Faust (who had been seduced by Mephistopheles) is redeemed and purified by Mary/Madonna in Heaven. So much so that she is -once again, thanks to Mary/Madonna - endowed with the power to grant salvation to Faust, who had died as a corrupted old man.

The success of Madonna is the ability to build Maria Puder as a dynamic female character who oscillates between contrasting images of physical and spiritual female beauties just like Margarete. Even the naming Madonna in a Fur Coat embodies such a polysemous and ambivalent dynamism. As stated above, this naming refers on the one hand to a Hungarian-Jewish woman who was a violinist in a women's orchestra performed in Istanbul; on the other hand, to the self-portrait that Raif falls in love with (the way Faust falls in love with Helen of Troy as soon as he spots her reflection on the mirror) which is renamed by an art critic in a review. In the framework of this article, the second renaming deserves attention. In what follows Raif paraphrases this review for the reader:
...the critic concluded by saying that (by uncanny coincidence) the woman in the painting bore, in both expression and manner, a striking resemblance to Andrea del Sarto's depiction of the Mother Mary in his Madonna delle Arpie. In a slightly humorous tone, he wished the 'Madonna in a Fur Coat' every success, before moving on to discuss another work that had caught his eye. (Ali, 2016, p. 89)

Hence, here the text itself exposes where the naming Madonna in a Fur Coat derives from. Critics and researchers of Madonna must have found these intra-textual and extratextual information sufficient, as they did not try to further investigate the potential intertextual sources of the nickname Madonna. However, when the naming and characterisation of Madonna is considered intertextually, the first reference that occurs to mind is Freud's Madonna-whore complex theory, which is

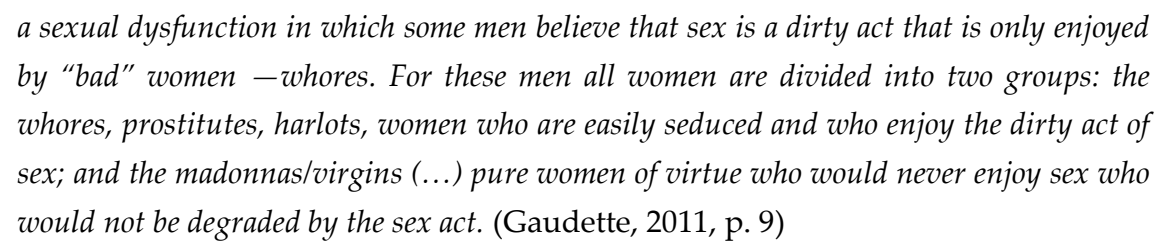

On this basis, one can recall that Raif falls into serious paranoid doubts about the "real face" of Maria Puder after she makes her acquaintance. He constantly oscillates between a "Maria as a prostitute" and a "Maria as a spiritual, motherly figure" (which is based on the self-portrait he fell in love with). Which one is she? The answer is already implied through the nicknaming as Madonna. It is also foreshadowed when Maria decides giving birth to her 
daughter at the expense of her life which is an explicit reference to Christian altruism. Maria Puder is the very saintly, motherly figure corresponding to the image of Madonna that Raif has desperately, in a very Oedipal manner, been searching for.

Furthermore, Freud describes men who suffer from this complex as "Where such men love, they have no desire and where they desire, they cannot love" (as cited in Gaudette, 2011, p. 9). In contrast with Freud's thesis, Raif does not feel any attraction for Maria Puder even when she behaves in a flirtatious and seductive way, for example, while she sings in a "vampish" manner at the cabaret. In the opposite, he falls in love with her when he realises that she has a beauty which is sublime, maternal, and spiritual, as her nickname Madonna implies. Thus, although Raif paranoidally exalts Maria Puder to a Madonna figure, this does not cause any sexual dysfunction. In this way, Ali as the author of the novella, intends to debunk Freud's thesis. Consequently, by naming his heroine as well as his work as Madonna in a Fur Coat which is a very useful phrase for concisely capturing both the otherworldly/spiritual and worldly/materialistic images - Ali does not only refer to autobiographical and Faustian elements, he also subtly parodies Freud's Maddona-whore complex theory.

Additionally, the combination of such factors as relying upon the whole text of Faust (instead of relying exclusively upon Faust, Part One as did Mori in The Dancing), critically referring to Freud's Maddona-whore complex theory and the outstanding poetic expressive power of Ali enabled Madonna to become one of the best love stories of world literature. A convenient example to this romantic aesthetic could be the following passage that externalises -through the figure of personification - the fragile and sensitive mood of a man waiting for the woman "he loves to worship":

Skirting the southern side of the Tiergarten, I took my time, finally arriving at a canal. I could see Maria Puder's house from the bridge. It had only just gone three. The sun was shimmering on the windowpanes: I couldn't make out anyone behind them. So I leaned against the railing on the bridge and looked down at the still waters. Soon those same waters were quivering in a haze of raindrops. (Ali, 2016, p. 142).

\section{CONCLUSION}

The Dancing and Madonna are non-European literary works that are both popular in their country and widely read abroad through translations. Their creative and deconstructive intertextual dances with some works of European literature, principally with Goethe's Faust, played a considerable part in their national and international reputation. Nonetheless, the factors that paved the way for their popularities are totally different. For instance, The Dancing became a bestseller, mainly because Mori attempted to produce a romantic story modelling after Faust, Part One. Consequently, Mori failed to write a "love story" because he paradoxically ignored Faust, Part Two which is far more romantic, in the broadest sense of the term, than Part One. Nonetheless, the Japanese readers of the late $19^{\text {th }}$ century perceived its new style and content as unique and authentic. Finally, this short story became ironically the founding text of sui generis Japanese romanticism.

In contrast, as previously mentioned, Ali's Madonna is one of the best love stories of world literature. Nevertheless, it was regarded as a failure from the time of its publication in 1943 until 2010s where it was rediscovered. Because realism was then seen as the ideal and only way of proper literary production, and a romantic "love story" like Madonna did not comply with the modern realist criteria, it was immediately labelled as outdated and 
anachronic. For the reason of not being modern enough, of not meeting the expectations of both the critics and readers, Ali's novella was marginalised and underestimated in the canon of modern Turkish literature. Hence, whereas The Dancing, which was not romantic enough, even close to realism, became popular as the critics and readers found it romantic, Madonna was underrated for the very reason of being romantic. Ironically, the most important factor which paved the way for its rediscovery after many decades by the readers of $21^{\text {st }}$ century, who are free from the restrictions of modern literature's intellectual censorship, is Madonna's stunning expressive power to verbalise "love."

In this article we compared two similar non-European texts which do not have direct intertextual links. We particularly focused on "how" the two texts, i.e. Mori Ōgai's The Dancing Princess and Sabahattin Ali's Madonna in a Fur Coat, involved in intertextual dances with Goethe's Faust. We analysed how these two non-European texts deformed, deconstructed, and reconstructed common themes, motifs, and techniques such as "love," "woman worship" and "translation" they borrowed from Faust. With this study we aim to provide a model for and contribute to the enhancement of the intertextual studies on nonEuropean texts. 
Article Information

Ethics Committee Approval: Informed Consent:

Financial Support:

Conflict of Interest:

Copyrights:

Exempt from the Ethics Committee Decision.

No participant.

No financial support from any institution or project.

No conflict of interest.

No material subject to copyright is included. 


\section{BIBLIOGRAPHY}

Ahmad, A. (1994). In theory: Classes, nations, literatures. London: Verso.

Ali, S. (2015). Kürk mantolu Madonna. İstanbul: Yapı Kredi Yay.

Ali, S. (2016). Madonna in a fur coat. London: Penguin Books.

Apter, E. (2003). Global translatio: The 'invention' of comparative literature, Istanbul, 1933. Critical Inquiry, 29(2), 253-281.

Auerbach, E. (1946). Mimesis: The representation of reality in Western literature. Bern: A. Francke Verlag.

Bassnet, S. (1998). Comparative literature - A critical introduction. Oxford: Blackwell.

Bezirci, A. (2007). Sabahattin Ali: Yaşamı, kişiliğgi, sanatı, hikayeleri, romanları. İstanbul: Evrensel Yay.

Damrosch, D. (2003). What is world literature?. Princeton, N.J: Princeton University Press.

Eagleton, T., Jameson, F. \& Said, E. (1990). Nationalism, colonialism, and literature. Minneapolis, London: University of Minnesota Press.

Freely, M. (2016, May 21). Sabahattin Ali's Madonna in a fur coat-The surprise Turkish bestseller. The Guardian. Retrieved from

https://www.theguardian.com/books/2016/may/21/sabahattin-ali-madonna-fur-coatrereading.

Gaudette, P. (2011). Madonna/whore complex-Love without sex, sex without love. London: Home Leisure Pub.

Goethe, J. W. v. (2014). Faust I \& II. (S. Atkins, Trans. \& Ed.). New Jersey: Princeton University Press.

Güven, D. Ç. (2018). 21. yüzyıl postmodern Japon edebiyatının aykırı sesleri: İkezava Natsuki, Seirai Yūiçi ve Kobayaşi Takici. In A. Atay (Ed.), Japon dili incelemeleri / Nihongo shokenkyū (pp. 15-35). London: Transnational Press.

Güven, D. Ç. (2020). Foucauldian "medical gaze" as an ideological apparatus of modern power structures in the works of Rifat Ilgaz, Ooka Shohei, Jean-Paul Sartre and Joseph Conrad. Folklor/Edebiyat, 26(1), 157-171. doi: 10.22559/folklor.1148.

Jameson, F. (1986). Third-world literature in the era of multinational capitalism. Social Text, 15, 65-88. doi:10.2307/466493.

Karatani, K. (2004). Nihon kindai bungaku no kigen. Teihon. (『日本近代文学の起源. 定本』). Tokyo: Iwanami Shoten.

Keene, D. (2007). Modern Japanese literature: From 1868 to the present day. New York, NY: Grove Press.

Kurczynski, K. (2014). The Art and politics of Asger Jorn: The avant-garde won't give up. Ashgate: Burlington Press.

Moretti, F. (2000). Conjectures on world literature. New Left Review 1 (4), 54-68.

Mori, Ō. (2011). The dancing girl (R. Bowring, Trans.). In J. T. Rimer \& V. C. Gessel (Eds.), The Columbia anthology of modern Japanese literature (pp. 8-23). New York, NY: Columbia University Press.

Rimer, J. T. \& Gessel, V. C. (Eds.). (2011). Preface. In The Columbia anthology of modern Japanese literature (pp. 7-8). New York, NY: Columbia University Press.

SEFAD, 2021; (45): 81-100 
Said, E. W. (1978). Orientalism. New York: Pantheon Books.

Said, E. W. (1994). Culture and imperialism. New York: Knopf.

Sertel, M. Z. (1977). Hatırladıklarım. İstanbul: Can Yay.

Takahashi, K. (1960). German literature in Japan. Japan Quarterly, 7(1), 193-199.

Takahashi, K. (1993). Mori Ōgai. In K. Isoda et al. (Eds.), Shinchō Nihon Bungaku Jiten (pp. 1246-1250). Tokyo: Shinchō-sha.

Tanizaki, J. (2010). Some prefer nettles (E. G. Seidensticker, Trans.). London: Penguin Books.

Wellbery, D. E. (2014). Introduction. In J. W. v. Goethe, Faust I \& II (pp. xi-xxiv). New Jersey, NJ: Princeton University Press.

Wellek, R. \& Warren, A. (1949). Theory of literature. London: Jonathan Cape. 